\title{
Impacts of climatic condition on different Brassica genotypes growth and productivities
}

\author{
Jahangir Ahmed ${ }^{1}$, Saadullah Khan Leghari ${ }^{2 *}$, Abdullah Baloch ${ }^{3}$, Atta \\ Muhammed Sarangzai ${ }^{2}$, Muhammed Saeed ${ }^{1}$, Mujahid Iqbal ${ }^{1}$, \\ Muhammad Yaqoob ${ }^{3}$, Shafiq Ahmed ${ }^{3}$, Sana-ur-Rahman ${ }^{4}$ and \\ Muhammed Zeeshan Danish ${ }^{5}$ \\ 1. Agriculture Research Institute, Sariab Road, Quetta, Balochistan, Pakistan \\ 2. Department of Botany University of Balochistan Quetta, Pakistan \\ 3. Balochistan Agriculture Research \& development Center Brewery Road, Quetta, Pakistan \\ 4. Institute of Management Sciences, University of Balochistan Quetta, Pakistan \\ 5. University College of Pharmacy, University of Punjab, Lahore, Pakistan \\ *Corresponding author's email: saadbotany@yahoo.com \\ Citation \\ Jahangir Ahmed, Saadullah Khan Leghari, Abdullah Baloch, Atta Muhammed Sarangzai, Muhammed Saeed, \\ Mujahid Iqbal, Muhammad Yaqoob. Shafiq Ahmed, Sana-ur-Rahman and Muhammad Zeeshan Danish. Impacts of \\ climatic condition on different Brassica genotypes growth and productivities. Pure and Applied Biology. Vol. 5, \\ Issue 3, pp594-600. http://dx.doi.org/10.19045/bspab.2016.50077
}

\begin{tabular}{llll}
\hline \hline Received: 28/10/2015 & Revised: 24/05/2016 & Accepted: 02/06/2016 & Online First: 17/06/2016
\end{tabular}

\section{Abstract}

During 2015 to compare the yield performance of seven Brassica genotypes under the Agroclimatic condition of Quetta were studied. The treatments was consist of V1 (Hyola-401), V2 (BARD - 1), V3 (Raya Anmol), V4 (CON II), V5 (Sarhein - 95), V6 (19- H) and V7 (Canola Raya). Between all the seven examined varieties of Brassica genotypes the CON II and BARD1 gave greatest seed yield $\left(898 \mathrm{~kg} \mathrm{ha}^{-1}\right)$ and $\left(889.33 \mathrm{~kg} \mathrm{ha}^{-1}\right)$ respectively, with better yield components like biological yield, plant height and one thousand seeds weight as contrasted to other varieties. It is accomplished that CON II and BARD-1Brassica genotypes executed good and attained greatest productivities with excellent quality under agro climatic condition of Quetta.

Key words: Brassica genotypes; yield; Climatic Condition; Balochistan; Quetta

\section{Introduction}

Due to high population growth in Pakistan the requirement for food is rising and it is putting a great stress on agriculture sector [1]. In view of rising population and increased standard of live in 21 century, the demands of edible oil have been increased. Researchers are trying level best to find ways to produce quality edible oil with increased yield. Majority population of Pakistan is directly or indirectly dependent on Agriculture sector. In Pakistan, there is still lack of extremely significant human diet elements such as eat able oil in spite of some development in agriculture field like independency in foodstuff together with wheat and cotton particularly. About 223 thousand acres are currently under cultivation with 136 thousand tons oilseed of total production. As compared to the developed countries of the world Pakistan's 52 thousand tons of oil production that is much less [2]. Due to the competition with other crops the productivity of Brassica in 
not increasing in Pakistan. Sarwar et al. [3] stated that a few efforts could be put forth to increase production in the course of vertical expansion. Vertical expansion could increase planting improved, or hybrids varieties.

Canola belonging to the Brassica family is highly popular among formers in Pakistan and in the world that is considered one of the important sources of eatable oil. Brassica oil is also an important ingredient in the field of bio-diesel. Owning better contents of protein and fewer fibers, the leaves and stems of canola provide high quality forage matter, in addition to oil production [4, 5]. Brassica napus L. (Canola) has a specific type of rapeseed connected with great quality meal and oil. Its meal has less than $30 \mu \mathrm{g}$ of glucosinolate and fewer than $2 \%$ erucic acid. Canola holds $36-40 \%$ protein contents and $40-45 \%$ oil contents [6]. Canola oil and meal are now considered very important sources as alternatives to soya bean oil and meal $[6,7]$. There are a number of factors that could be explored related to the feeding of 200 million people of Pakistan and boosting the local cooking oil industry. Blum [8] stated that the use of hybrids/improved cultivars is one the most important factor with great production potential and vigor may improve the yield of the crop. Due to high oil contents and yield the Canola crop has the potential to a bridge the gap between local production and consumption. Canola crop requires the same land and water as required by the rapeseed/mustard oilseed crops. Therefore, it may not be difficult for farmers to adapt and manage cultivation practices of canola crop.

In Pakistan after cotton seed oil the mustard and rapeseed is second predictable oil producing crops. The good management and improved varieties are vital tools for great development in several states of the world. For achieving higher yields, in addition to many other factors responsible the genotypes of great yield potential and a broad choice of flexibility in different climatic circumstances is necessary means for improving yield in particular area and at the end increasing the total productivity. In present days, several kinds of Canola has been introduced and cultured but productivity potentials have not been still investigated in Pakistan.

The assortment of appropriated variety always plays a vital role in getting high yield of a crop [9]. Younesi and Moradi [10] stated that ecological pressure like control of water throughout growth and development of vegetation is able to have an effect on seed superiority and number of seed. Some physiological and agronomic parameters such as plant height, pod length, number of seed per pod, number of pods per plant, 1000 seed weight, index of leaf area, growth rate of crop, leaf area index and whole dehydrated stuff showed certain variations in various canola cultivars. As compared to Brassica napus the Brassica juncea produced significant higher yield and yield components. Iqbal et al .[11] indicated that Brassica napus showed minimum contents of glucosinolates and erucic acid as compared to Brassica juncea in seed oil. Cheema et al. [12] deliberated the relative productivity and growth rate performance of six Brassica varieties and they indicated considerably variation between the number of branches plant ${ }^{-1}$, number of pods plant ${ }^{-1}$, plant height, seed yield $\mathrm{kg} \mathrm{ha}^{-1}, 1000$ seed weight, and harvest index and nonsignificant difference were observed in number of seeds pod ${ }^{-1}$. Abbasian and Shirani $\mathrm{Rad}$ [13] reported that as compared to water stress the time of occurrence and climatic condition is more important for quality and production of any crop. Inayt et al. [14] evaluated the rapeseed genotypes for total yield and oil quality under rain fed condition of district Mansehra. They showed 
significant differences in number of seeds per pod, per plant number of pods, weight of one 1000 seeds, inflorescence length, pedicle length, and length of pod, plant height, per plant total yield, yield $\mathrm{kg} \mathrm{ha}^{-1}$ and oil \% among the genotypes. Cheema et al. [15] investigated a range of Canola cultivars under Agro - ecological condition of Faisalabad and noticed a significant variations among the varieties in total dry matters accumulation, crop growth rate (CGR), leaf area index, yield and yield components.

The main objective of this investigation was to evaluate the productivity potential and Quality of various Brassica genotypes under sami-arid climatic condition of Quetta Balochistan, Pakistan.

\section{Materials and methods}

During spring 2015 a comparative study was conducted at agriculture institute for research Sariab Quetta for the total yield productivity of seven selected varieties of Brassica. Randomized Complete Block Design (RCBD) was applied for the experiment performance with three replications by using net plot size of $5 \mathrm{~m} \mathrm{x}$ $8 \mathrm{~m}$. The treatments were included V1 (Hyola-401), V2 (BARD - 1), V3 (Raya Anmol), V4 (CON II), V5 (Sarhein - 95), V6 $(19-\mathrm{H})$ and V7 (Canola Raya). By the using of $5 \mathrm{~kg} \mathrm{ha}^{-1}$ seed with spacing of 45 $\mathrm{cm}$ rows were sown on $10^{\text {th }}$ march 2015 in well prepared seed bed with the help of one row hand drill. In the form of triplesuperphosphate and urea the Phosphorus and Nitrogen fertilizers were used at the rate of $60 \mathrm{~kg} \mathrm{P} \mathrm{ha}{ }^{-1}$ and $90 \mathrm{~kg} \mathrm{~N} \mathrm{ha}^{-1}$, respectively. All the Phosphorus and 1/3 of Nitrogen were applied as a basal quantity. The left over $2 / 3$ Nitrogen was put into practice in two equivalent divisions (1/2 at first irrigation and $1 / 2$ at developing stage). During entire period of growth the crop was irrigated three times. After sowing of the 30 days the first irrigation was done, second at the flowering and third at the start of seed development. After one month for maintaining the space of $10 \mathrm{~cm}$ with in the plants the thinning was done twice. For protecting the field from weeds the two hoeing was given. Insecticides were applied to control the aphids. All the treatment was kept normal and uniforms under all the agronomic practices. Ten plants were selected randomly from each plot for the measurement of height of plant, per plant number of pods, per pod number of seeds, weight of one 1000 seeds, biological productivity $\mathrm{kg} \mathrm{ha}^{-1}$, total yield $\mathrm{kg} \mathrm{ha}^{-1}$ and index \% of harvest. From each treatment the total yield were documented by means of randomly chosen $3 \mathrm{~m} \times 3 \mathrm{~m}$ crop. The pods number was noted on the average of 10 plants as of every behavior. The recorded results were analyzed statistically as mean values of three replications and data was also analyzed by the analysis of variance (ANOVA) by using the methods described by Gomez \& Gomez [16]. Among the means the significance of difference was compared by using Least Significant Difference (LSD) Test [17].

\section{Recorded observations}

Plant height (cm)

Plant height $(\mathrm{cm})$ was measured with the help of measuring tape. It was measured from each replication of 10 randomly selected plants from base to tip of the plant.

\section{Per plant number of pods}

From ten randomly selected plants number of pods was counted and then average was calculated for number of pods per plant.

\section{Number of seed pod $^{-1}$}

Number of seed per pod was determined by counting seeds from 10 randomly selected pods from each replication and then average number of seeds per pod was considered.

\section{Weight of 1000 seed (g)}

1000 seed weight was determined by weighting 1000 seeds from each replication and the average weight in gram was calculated. 
Biological yield Kg ha ${ }^{-1}$

For the determination Biological Yield $\mathbf{k g}$ $\mathbf{h a}^{-1}$ each plot was weighted at its maturation after harvesting and then average was considered for Biological yield $\mathbf{k g ~ h a}^{\mathbf{- 1}}$.

\section{Seed yield $\mathrm{kg} \mathrm{ha}^{-1}$}

For seed yield $\mathrm{kg} \mathrm{ha}^{-1}$ each plot was harvested at its maturation stage and seed yield were computed on per ha basis.

\section{Results and discussion}

Plant height (cm)

Both the genetic and environmental factors are responsible for the plant height of a crop. The data illustrated in Table 1 indicated that the variation in genotypes of Brassica is considerably affected in the form of plant height. Highest height of plant $(99.43 \mathrm{~cm})$ was noted in Brassica genotype CON 11. While the lowest plant height $(82.76 \mathrm{~cm})$ was observed in Sarhein - 95 varieties. This greatest height of plant in CON 11 might be due to the characteristic of genetics. The observation reported by other researchers $[14,18,19]$ also supported these observations. They found variations in plant tallness in divers Brassica varieties.

\section{Per plant number of pods}

Per plant number of pods is considered a main yield part of Brassica genotype toward seed productivity. In present investigation per plant numbers of pods was influenced through diverse genotypes of Brassica. The highest per plant number of pods (97.7) was noticed inside CON 11 Brassica genotype (Table 1). The significant variation regarding number of pods per plant in Brassica varieties might be because of their inherited latent. On the other side the Brassica variety Raya Anmol showed lowest numbers (81.76) of pods per individual. The finding of other researcher $[14,18,19]$ supported these results. They indicated important variations in per individual pods with in different genotypes of Brassica.

\section{Per pod number of seeds}

Results illustrated in Table 1, showed important variations in per pod number of seeds in different Brassica varieties. The highest number of seeds per pod was noted in Sarhein (36.5) and lowest was in Brassica genotype Hyola - 401 (14.2). These results corroborate the findings of other investigaters $[14,18,19]$ they reported significant variations in per pod number of seeds in diverse types of Brassica plants. Further that the yield of seed had significant positive correlation with per plant number of pods [20].

Table 1.Response of different Brassica genotypes under agro climatic condition of Quetta Balochistan, Pakistan

\begin{tabular}{|l|c|c|c|}
\hline Varieties Name & Plantheight $(\mathbf{c m})$ & Number of pods plant & Number of seed pod $^{-\mathbf{1}}$ \\
\hline Hyola-401 & $91.767 \mathrm{E}$ & $72.367 \mathrm{~F}$ & $14.200 \mathrm{~F}$ \\
\hline BARD - 1 & $93.933 \mathrm{D}$ & $83.733 \mathrm{C}$ & $16.700 \mathrm{E}$ \\
\hline Raya Anmol & $96.333 \mathrm{C}$ & $81.767 \mathrm{D}$ & $20.167 \mathrm{C}$ \\
\hline CON II & $99.433 \mathrm{~A}$ & $97.700 \mathrm{~A}$ & $24.700 \mathrm{~B}$ \\
\hline Sarhein - 95 & $82.767 \mathrm{G}$ & $90.200 \mathrm{~B}$ & $36.500 \mathrm{~A}$ \\
\hline 19- H & $89.800 \mathrm{~F}$ & $75.567 \mathrm{E}$ & $18.00 \mathrm{D}$ \\
\hline Canola Raya & $97.700 \mathrm{~B}$ & $83.400 \mathrm{CD}$ & $17.10 \mathrm{E}$ \\
\hline Grand Mean & 93.105 & 83.533 & 21.052 \\
\hline CV & 0.51 & 1.11 & 1.70 \\
\hline LSD 5\% & 0.3853 & 0.7562 & 0.2917 \\
\hline
\end{tabular}




\section{Weight of one thousand seeds (g)}

For final yield of a crop, weight of one thousand seeds also play important role in determination of total yield. Variation in cultivars significantly put pressure on the 1000 -seeds weight. The maximum weight of 1000 -seeds $(18.36 \mathrm{~g})$ was obtained from BARD-1 variety, while the minimum weight of 1000 -seeds (14.10 g) and (13.40 g) was reported in Sarhein and Canola Raya (Table 2). The highest weight of 1000 seeds recorded in BARD-I Brassica genotype might be obtained because of good source sink association as compared to the other genotypes. The present data were similar to the finding of other researchers [14, 18, 19] who's found significant variations for 1000-seeds weight.

\section{Biological yield $\left(\mathrm{kg} \mathrm{ha}^{-1}\right)$}

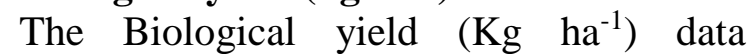
presented in Table 2 indicated significant variation according to the variation of Brassica varieties. The maximum biological yield $\mathrm{kg} \mathrm{ha}^{-1}$ was produced by the variety BARD - $1\left(21,863 \mathrm{~kg} \mathrm{ha}^{-1}\right)$, these finding are quite in line with the finding of other researchers [14, 18, 19]. They indicated non considerable variations in Biological productivity of various genotypes of Brassica.

Table 2. Response of different Brassica genotypes under agro climatic condition of Quetta Balochistan, Pakistan

\begin{tabular}{|l|c|c|c|}
\hline Varieties Name & 1000 seed weight $(\mathbf{g})$ & Biological yield kg ha-1 & Total Seed yield kg ha' $^{-1}$ \\
\hline Hyola-401 & $17.133 \mathrm{~B}$ & $19565 \mathrm{C}$ & $690.67 \mathrm{ABC}$ \\
\hline BARD - 1, & $18.367 \mathrm{~A}$ & $21863 \mathrm{~A}$ & $889.33 \mathrm{~A}$ \\
\hline Raya Anmol & $15.867 \mathrm{C}$ & $17567 \mathrm{D}$ & $837.67 \mathrm{AB}$ \\
\hline CON II & $17.70 \mathrm{AB}$ & $20795 \mathrm{~B}$ & $898.00 \mathrm{~A}$ \\
\hline Sarhein - 95 & $14.10 \mathrm{D}$ & $17884 \mathrm{D}$ & $773.33 \mathrm{ABC}$ \\
\hline $\mathbf{1 9}-\mathbf{H}$ & $17.93 \mathrm{~A}$ & $20137 \mathrm{BC}$ & $674.33 \mathrm{BC}$ \\
\hline Canola Raya & $13.40 \mathrm{D}$ & $14132 \mathrm{E}$ & $595.67 \mathrm{C}$ \\
\hline Grand Mean & 16.357 & 18849 & 765.57 \\
\hline CV & 2.52 & 3.00 & 15.65 \\
\hline LSD 5\% & 0.3372 & 461.92 & 97.848 \\
\hline
\end{tabular}

Total yield of seeds $\mathrm{Kg} \mathrm{ha}^{-1}$

Total seed yield actually showed combined components of different productivities such as; per individual number of pods, per pod number of seed and one thousand seeds weight of a crop. In the present study the total seed productivity was significant affected due to variation in climate condition and variation in Brassica genotypes. Highest total productivity of seed $\left(898 \mathrm{~kg} \mathrm{ha}^{-1}\right)$ and $\left(889.33 \mathrm{~kg} \mathrm{ha}^{-1}\right)$ was indicated by the CON II and BARD-1 Brassica varieties respectively, while the minimum seed yield $\left(595.67 \mathrm{~kg} \mathrm{ha}^{-1}\right.$ ) was achieved by Canola Raya (Table 2). Highest total productivity of seed by
BARD-I Brassica genotype accredited to better yield components as compared to the other genotypes. Finding of other researchers [14, 18, 19] confirmed these results as they were investigating the different species of Brassica plant their finding indicated that the maximum yield of seeds were produced by Brassica compestris. Moreover other researchers [20] establish that seed yield have important optimistic association by number of pods and number of branches per plant in drought and different climatic conditions. Along with total yield components such as the number of pods per plant and number of seed per plant 
showed maximum pressure on total seed yield. Our outcome was alike to the conclusion of other researcher [21- 23].

\section{Conclusion}

On the behalf of the present investigation it was concluded that all the investigated parameters showed significant variation due to difference in Brassica genotypes and climatic conditions. Among all the examined varieties the Brassica genotype BARD -1 was out standing in Seed yield $\mathrm{kg} \mathrm{ha}{ }^{-1}$ and Biological yield $\mathrm{kg} \mathrm{ha}{ }^{-1}$ fallowed by CON II. Therefore the Brassica genotypes BARD - $1 \&$ CON- II are suggested for wide ranging forming and further use in breeding programs for Brassica under agro-ecological conditions of Quetta Balochistan, Pakistan. The Brassica genotype Canola Raya reported nominal amount of seed yield that is why it should be avoided for the farming in Quetta region.

\section{Authors' contributions}

Conceived and designed the experiments: J Ahmed \& SK Leghari, Performed the experiments: SK Leghari, J Ahmed, A Baloch \& M Iqbal, Analyzed the data: Sana-ur-Rahman, MZ Danish \& AM Sarangzai, Contributed reagents/ materials/ analysis tools: M Saeed, M Yaqoob \& S Ahmed, Wrote the paper: SK Leghari \& J Ahmed.

\section{References}

1. Anonymous (2013). Economic Survey of Pakistan 2012-13. Ministry of Food and Agriculture.

2. Ministry of Finance (2008). Economic Survey of Pakistan 2007-08. p. 24-25. Finance and Economic Affairs Division, Govt of Pakistan, Islamabad, Pakistan.

3. Sarwar M, Ahmad N, Siddiqui QH, Ali A \& Tofique M (2004). Genotypic response in canola (Brassica species) against aphid attack. The Nucl. 41: 8792.

4. Wiedenhoeft M \& Barton BA (1994). Management and environment effects on Brassica forage quality. Agron $J$ 86: 227-237.
5. Bañuelos G S, Bryla DR \& Cook CG (2002). Vegetative production of kenaf and canola under irrigation in central California, Industrial Crops and Products 15: 237-245.

6. Tahir M, Ali A, Nadeem MA, Tanveer A \& Sabir QM (2007). Performance of canola (Brassica napus L.) Under different irrigation levels. Pak J Bot. 39: 739-746.

7. Amin R \& Khalil SK (2005). Effect of pre- and post-emergence herbicides and row spacing on canola. Sarhad $J$ Agric. 21: 165-170

8. Blum A (2004). Sorghum physiology. In: Physiology and biotechnology integration for plant breeding. $2^{\text {nd }}$ ed. Marcel Dekker, New York p. 141223.

9. Sana M, Ali A, Malik MA, Saleem MF \& Rafiq M (2003). Comparative yield potential and oil contents of different canola (Brassica napus L.) cultivars. Pak J Agron. 2: 1-7.

10. Younesi O \& Moradi A (2009). The effect of water limitation in the field on sorghum seed germination and vigor. Aust J Basic ApplSci 3(2): 1156-1159.

11. Iqbal M, Akhtar N, Zafar S \& Ali L (2008). Genotypic responses for yield and seed oil quality of two Brassica species under semi-arid environmental conditions. South Afr J Bot. 74:567571.

12. Cheema MA, Malik MA, Hussain A, Shah SH \& Basra SMA (2001a). Effects of time and rate of nitrogen and phosphorus application on the growth and the seed and oil yields of canola (Brassica napus L.). J Agron Crop Sci. 186:103-110.

13. Abbasian A \& Shirani RAH (2011). Investigation of the response of rapeseed cultivars to moisture regimes in different growth stages. $J$ Cent EurAgr. 12(2): 353-366.

14. Inayt $R$, Ahmad $H$, Inamullah, Sirajuddin, Ahmad I, Abbasi F M, Islam M \& Ghafoor S (2009). 
Evaluation of rapeseed genotypes for yield and oil quality under rainfed conditions of district Mansehra. Afric J Biotech 8(24):6844-6849.

15. Cheema MA, Sattar MA, Wahid MA, Saleem MF \& Sadiq S (2012). Growth, Yield and Quality response of various Canola cultivars under Agroecological condition of Faisalabad. Pak J Agric Sci. 49(1):35 - 39.

16. Gomez KA \& Gomez AA (1984). Statistical procedures for agricultural research. Wiley, New York, 680pp.

17. Steel RGD \& Torrie JH (1994). Principles and Procedures of Statistics. 2nd ed. Mc Graw Hill Book Co. Inc., Singapore: 173-7.

18. Cheema MA, Malik MA \& Basra SMA (2001). Comparative Growth and yield performance of different Brassica varieties. Int J Agri \& Biol 03(1): 135137.

19. Islam M, Ahmad H, Rashid A, Khan A, Razza A \& Derawadan H (2004).
Comparative study of agronomic traits of rapeseed genotypes under swat conditions. Pak J Plant Sci. 10: 31-33.

20. Sadaqat HA, Nadeem Thahir MH \& Hussain MT (2003). Physiogenetics aspects of drought tolerance in canola (Brassica napus L.). Int J Agri Biol. 5: 611-614.

21. Biabani AR, Pakniyat $\mathrm{H}$ \& Naderikharaji R (2008). Effect of drought stress on photosynthetic rate of four rapeseed (Brassica napus L.) cultivars. J Appl Sci. 8(23): 44604463.

22. Singh SP (2007). Drought resistances in the race Durango dry bean landraces and cultivars. Agron J. 99: 1219-1225.

23. Aliabadi FH, Valadabadi SAR, Daneshian J \& Khalvati MA (2009). Evaluation of changing of essential oil of balm (Melissa officinalis L.) under water deficit stress conditions. J Med Plant. 3(5): 329-333. 